\title{
PEMANFAATAN AIR REJECT REVERSE OSMOSIS DI UNIT HEMODIALISA RSUD BANYUMAS TAHUN 2017
}

\author{
Niken Wita Pratiwi ${ }^{1}$ ), Sugeng Abdullah ${ }^{2}$ ) \\ Jurusan Kesehatan Lingkungan, Politeknik Kesehatan Kemenkes Semarang, \\ Jl.Raya Baturaden KM 12 Purwokerto, Indonesia
}

\begin{abstract}
Abstrak
Rumah Sakit Umum Daerah Banyumas memiliki layanan untuk hemodialisis (cuci darah). Proses hemodialisis ini membutuhkan air khusus hemodialisa. Air yang digunakan terlebih dahulu diolah dengan Reverse Osmosis.Proses tersebut menghasilkan air produk 36,6\% dan air reject 63,4\%. Selama ini air reject tidak dimanfaatkan. Kualitas dan kuantitas dari air reject pun belum diketahui. Tujuan penelitian ini adalah untuk mengetahui pemanfaatan air reject RO pada Unit Hemodialisa RSUD Banyumas.

Jenis penelitian ini adalah penelitian kualitatif dengan pendekatan verifikasi/pengujian. Yaitu menggambarkan atau mendiskripsikan kondisi kualitas dan kuantitas air reject beserta alternatif pemanfaatannya.Hasil penelitian debit air reject dalam sehari 21.000 liter, debit air air produk 12.100 liter, debit air baku 33.100 liter. Kualitas fisik,kimia dan bakteriologis air baku yaitu suhu air $27,7^{\circ} \mathrm{C}$, suhu udara 30,5 $\mathrm{C}$, tidak berbau, tidak berasa, warna 1,4 TCU, kekeruhan 0,89 NTU, TDS $159 \mathrm{mg} / \mathrm{l}$, kesadahan $\mathrm{Ca}^{++}$8,75 , $\mathrm{Mg}^{++}$21,6, sisa chlor 0,2 mg/l, pH 8,2, Daya Hantar Listrik $265 \mu / \mathrm{cm}$, E coli dan Coliform 0 per $100 \mathrm{ml}$ sampel. Kualitas fisik,kimia dan bakteriologis air reject yaitu suhu air $27,7^{\circ} \mathrm{C}$ suhu udara $29^{\circ} \mathrm{C}$, tidak berbau, tidak berasa, warna 1,3 TCU,kekeruhan 0,16 NTU,TDS $289 \mathrm{mg} / \mathrm{l}$, kesadahan $\mathrm{Ca}^{++} 16, \mathrm{Mg}^{++} 40,8$, sisa chlor 0,1 mg/l , pH 8, Daya Hantar Listrik $482 \mu / \mathrm{cm}$, E.coli dan Coliform 240 per $100 \mathrm{ml}$ sampel.Air reject mesin reverse osmosis di RSUD Banyumas dapat dimanfaatkan tanpa atau dengan perlakuan. Air reject dapat dimanfaatkan sebagai air bersih dengan melakukan desinfeksi.
\end{abstract}

Kata kunci:cuci darah; reverse osmosis; air reject; pemanfaatan ; kesehatan lingkungan

\begin{abstract}
Generalhospital of Banyumas service for hemodialysis. This process of hemodialysis requines special water. The water used is firstly processed using Reverse Osmosis. Thoses process produces 36,6 \% product water and 63,4\% reject water. All along, reject water is unutilized. The goals research is to find out the reused of reject water RO on General Hospital of Banyumas hemodialysis unit.

The goals research is a qualitatif research using verification or examination approach. Which is to depict or describe the condition of reject water's quality and quantility along with its alternative reused.Research result reject water discharge is 21.000 litre a day, product water discharge is 12.100 litre. Source water discharge is 33.100 litre. Physical, chemical and bacteriological qualitys of source water are water temperature $27,7^{\circ} \mathrm{C}$, air temperature $30,5^{\circ} \mathrm{C}$, odorless, taste less, color 1,4 TCU, turbidity 0,89 NTU, TDS $159 \mathrm{mg} / \mathrm{l}$, hardness $\mathrm{Ca}^{++}$8,75 , $\mathrm{Mg}^{++}$21,6 , chlor residu 0,2 mg/l , Ph 8,2, electrical conductivity 265 umhos/cm, E.Coli and Coliform 0 per $100 \mathrm{ml}$ sample. Physical, chemical and bakteriologis qualities of reject water are : water temperature $27,7^{\circ} \mathrm{C}$, air temperature $29^{\circ} \mathrm{C}$, odor less, taste less, color 1,3 TCU, turbidity 0,16 NTU, TDS $289 \mathrm{mg} / \mathrm{l}$, hardness $\mathrm{Ca}^{++} 16, \mathrm{Mg}^{++}$40,8, chlor residu $0,1 \mathrm{mg} / \mathrm{l}, \mathrm{Ph}$ 8, electrical conductivity 482 umhos/cm, E.Coli and Coliform 240 per $100 \mathrm{ml}$ sample.Reject water of reverse osmosis in RSUD Banyumas can be reuse wether using treatment or no. Reject water can be reused as clean water by disinfection
\end{abstract}

Keywords:enviromental health, hemodialisis, reverse osmosis, reject water,reused 


\section{Pendahuluan}

Rumah sakit sebagai sarana pelayanankesehatan tempat berkumpulnya orang sakit maupun orang sehat, atau dapat menjadi tempat penularan penyakit serta memungkinkan terjadinya pencemaran lingkungan dan gangguan kesehatan.(Kepmenkes No 1204/Menkes/SK/X/2004).

Salah satu fasilitas dari RSUD Banyumas adalah hemodialisa.pencemaran. Yaitu pencemaran dari air,udara,tanah,dll.

Hemodialisa adalah proses pembersihan darah oleh akumulasi sampah buangan. Hemodialisis digunakan bagi pasien dengan tahap akhir gagal ginjal atau pasien berpenyakit akut yang membutuhkan yang membutuhkan dialisis waktu singkat. (Nursalam M, 2006)

Proses hemodialisa memerlukan operasional air. Pengolahan air untuk hemodialisa salah satunya menggunakan sistem RO. Air baku setelah masuk ke sistem RO akan diproses lebih lanjut. Atau bisa disebut dengan air produk RO. Namun, untuk air yang tidak lolos RO akan tertolak atau disebut air reject.

Menurut data yang diambil dari Unit Hemodialisa RSUD Banyumas pasien cuci darah di tahun 2015 mencapai 18.470 orang dengan 34 mesin. Dari tahun menahun pasien semakin meningkat. Hal ini dibuktikan dengan adanya penambahan mesin, pada tahun 2014 dengan 29 mesin dan tahun 2015 dengan 34 mesin. Serta juga ada penambahan shift kerja. 1 mesin dan 1 kali pencucian darah membutuhkan air produk RO 120 liter.

RSUD Banyumas bekerja sama dengan pihak ketiga dalam menanggani pengolahan air untuk hemodialisa. Salah satu proses nya menggunakan teknologi Reverse Osmosis ( RO ) . Air baku yang digunakan berasal dari PDAM ( Perusahan Daerah Air Minum ) dan sumur artesis.

Air baku tersebut masuk ke dalam proses RO. Yang lolos dari proses RO langsung masuk ke mesin/ filter selanjutnya. Data ISPL ( Instalasi Sanitasi dan Penyehatan Lingkungan ) RSUD Banyumas menyatakan bahwa air yang lolos dari sistem RO sebesar $15 \%$ dan air reject sebesar $85 \%$. Banyak air yang tidak lolos RO tersebut selama ini hanya dibuang dan tidak dimanfaatkan. Kualitas dari air reject RO tersebut selama ini belum diketahui.

Berdasakan data dari unit Hemodialisa RSUD Banyumas, untuk 1 kali melakukan cuci darah pada 1 mesin membutuhkan air produk RO 120 liter.

*)E-mail : nikenwita120@gmail.com

*)E-mail :sugengzend@gmail.com

Dari perhitungan yang telah dilakukan mendapatkan hasil bahwa, air baku yang digunakan yaitu 800 liter. Air rejectnya sebesar 680 liter. Pasien yang melakukan cuci darah setiap harinya sebanyak 70 orang. Berarti dalam satu hari, membutuhkan air baku 56.000 liter $\left(56 \mathrm{~m}^{3}\right)$. Air produk RO untuk 70 orang membutuhkan 8400 liter $\left(8,4 \mathrm{~m}^{3}\right)$. Dan menghasilkan air reject RO 47.600 liter $\left(47,6 \mathrm{~m}^{3}\right)$.

Reverse osmosis yaitu masuknya atau mengalirnya air yang berkonsentrasi tinggi ke dalam air yang berkonsentrasi rendah melalui membran semipermeabel. Proses didalam reverse osmosis ialah menyaring molekul yang lebih besar dari air, seperti molekul garam. Garam yang terpisah tersebut masuk kedalam air yang di tolak atau dibuang. (Arie Herlambangan, 2010, h.17)

Dengan memberikan tekanan osmosis yang lebih tinggi, maka air murni akan melewati membran semipermiabel ke sisi air yang encer. Ini merupakan proses pemisahan zat terlarut dari pelarutnya. Membran hanya dilewati oleh pelarut, untuk zat terlarutnya baik elektrolit maupun organik akan ditolak atau dibuang (direjeksi). Yang dapat melewati membran RO hanya air saja. Kotoran yang terbawa air akan dengan sendirinya tertolak atau terbuang (reject). Rejeksi dari membran bisa mencapai 95\%. Rejeksi bakteri,virus dapat dicapai $100 \%$. Kecuali apabila terdapat membran yang rusak ataupun terjadi kebocoran pada seal mekanis. Untuk penggunaan air yang mempersyaratkan bebas dari organisme, RO sangat sesuai untuk bidang farmasi dan kedokteran.( A.J Hartomo, M.C Widiatmoko, 1994, h. 43).

Berdasarkan permasalah yang ada, maka peneliti ingin mengambil judul yaitu “ Pemanfaatan Air Reject RO di Unit Hemodialisa RSUD Banyumas Tahun 2017 “

Tujuanriset ini adalah mengetahui pemanfaatan air reject RO pada Unit Hemodialisa RSUD Banyumas.

\section{Bahan dan Metode}

Bahanyang digunakan adalah air reject reverse osmosis. Air reject tersebut dilihat dari kualitas dan kuantitasnya melalui penakaran,perhitungan debit dan pemeriksaan laboratorium. Melakukan pemeriksaan kualitas air reject dan membandingkan dengan baku mutu untuk menentukan pemanfaatannya yang sesuai baku mutu. Baku mutu yang digunakan yaitu PP no 82 tahun 2001, Permenkes 416 tahun 1990, Permenkes 492 tahun 2010, Permenkes 32 tahun 2017.

Jenis Penelitian yang digunakan adalah penelitian Jenis penelitian yang digunakan yaitu 
penelitian kualitatif dengan pendekatan verifikasi/pengujian.Yaitu menggambarkan atau mendiskripsikan kondisi kualitas dan kuantitas air reject beserta alternatif pemanfaatannya.pengumpulan data dilakukan dengan penakaran air reject untuk menghitung debit, pengutipan debit air produk dan pengambilan sampel.

\section{Hasil dan Pembahasan}

\subsection{Gambaran Umum RSUD Banyumas}

Berdasarkan SK MenteriKesehatanNomor 850/ Menkes/ SK/ VIII/ 2001 Tanggal 5 Oktober 2001 RSUD Banyumasadalah RS Kelas B Pendidikan.RSUD Banyumas memiliki jumlah tempat tidur 429 buah. RSUD Banyumas beralamatkan di Jalan Rumah Sakit No 1 Desa Kejawar Banyumas. Data 2016 menunjukan BOR RSUD Banyumas sebesar 71,3 \%.

RSUD Banyumas memiliki lokasi yang strategis.Hal ini dikarenakan terletak pada jalur utama Purwokerto - Jogja.Nilai parameter BOR yang ideal adalah antara 60-85\% (Depkes RI, 2005).Data BOR tahun 2016 menunjukan bahwa RSUD Banyumas sudah ideal mengenai jumlah tempat tidur yang digunakan. Hal ini disisi lain memberikan dampak negatif dan positif. Dampak positif yaitu menguntungkan dari segi pendapatan.Dampak negatif yaitu dapat terjadinya infeksi nosokomial yang sangat tinggi apabila tidak diimbangi dengan sanitasi rumah sakit.

\subsection{Gambaran Kesehatan Lingkungan Rumah Sakit Umum Banyumas}

1. Penyehatan Ruang Bangunan dan Halaman Rumah Sakit

Semua ruang/unit dan halaman yang ada di dalam batas pagar rumah sakit (bangunan fisik dan kelengkapannya) yang dipergunakan untuk berbagai keperluan dan kegiatan rumah sakit.

Kegiatan sanitasi ruang bangunan yang dilakukan oleh petugas sanitasi seperti pengukuran pencahayaan, kelembaban dan suhu ruangan (kualitas lingkungan fisik udara).Setiap minggu dilakukan inspeksi kebersihan disemua ruangan.Dan disetiap bulannya dilakukan pengambilan sampel udara dan lantai, serta dilakukan pengukuran kualitas lingkungan fisik.

Kegiatan sanitasi ruang bangun yaitu melakukan inspeksi kebersihan ruangan, pengukuran kualitas lingkungan fisik danpengambilan sampel lantai, udara dan AC. Kondisi beberapa ruang terutama perawatan ada yang tidak memenuhi syarat, yaitu terletak pada lantai yang tidak dibuat konus. Menurut Kepmenkes 1204 tahun 2004 menyebutkan persyaratan kesehatan lingkungan pada aspek ruang bangun, lantai harus dibuat konus.Hal ini perlu dilakukan untuk mencegah terdapatnya bakteri pada sela-sela lantai dan memudahkan petugas dalam pembersihan.

2. Penyehatan Hygiene dan Sanitasi Makanan dan Minuman

Pengelolaan makanan dan minuman pada RSUD Banyumas dilakukan di Instalasi Gizi. Petugas Labkesda Banyumas melakukan pemeriksaan pada instalasi gizi setiap 6 bulan sekali dengan cara pengambilan sampel makanan pasien dan usap alat makan.

Hampir secara keseluruhan kegiatan hygiene dan sanitasi makanan minuman dilakukan instalasi gizi.Setiap bulan diambil sampel makanan minuman dan usap alat makan.Instalasi gizi melayani pasien dan karyawan.Pendistribusian dilakukan oleh pramuniaga.Distribusi makanan menggunkan troli makanan.Pendistribusian dilakukan 3 kali. Yaitu pada pagi,siang dan sore.

RSUD Banyumas belum memiliki jalur khusus untuk distribusi makanan. Jalurnya masih sama dengan jalur pengangkutan sampah dan loundry. Hal ini sebenarnya dapat terjadi kontaminasi lewat udara. Hal demikian dapat diatasi dengan pergatian jam distribusi antara makanan, sampah dan loundry.

\section{Penyediaan Air Bersih}

Sarana air bersih di RSUD Banyumas bersumber dari PDAM, sumur arthesis.Kualitas air secara umum menunjukkan mutu atau kondisi air yang dikaitkan dengan suatu kegiatan atau kebutuhan tertentu khususnya di Rumah Sakit.Kuantitas jumlah air juga mempengaruhi kebutuhan air yang digunakan di rumah sakit.Air bersih sangat dibutuhkan dalam pemenuhan kebutuhan untuk melakukan segala kegiatan.Untuk distribusi air bersih terdapat 4 tandon air dan setiap pagi di lakukan kaporitasi.Hal ini bertujuan untuk tetap menjaga air dari bakteri.Sistem jaringan distribusi air bersih di RSUD Banyumas menggunakan sistem gravitasi dan hydropure.Selama ini dari segi kualitas dan kuantitas tidak mengalami permasalahan.Dilakukan pengambilan sampel air setiap bulan sekali.

Dilihat dari segi kualitas ada beberapa persyaratan yang harus dipenuhi yaitu kualitas 
fisik seperti bau, warna dan rasa.Kualitas kimia seperti $\mathrm{pH}$, besi, kesadahan dan yang lainnya.Kualitas mikrobiologi yaitu terbebas dari bakteri pathogen.

Secara kuantitas penyedian air bersih di RSUD Banyumas sudah memenuhi untuk seluruh kegiatan yang ada.Terdapat beberapa tandon air pada ruangan khusus seperti ruang gizi dan bersalin.Hal ini dilakukan untuk menampung air bersih yang gunakan apabila terjadi kelangka air.Mengingat kegiatan diruangan tersebut sangatlah penting. Hal ini sudah bagus dan perlu dapat dijadikan contoh bagi rumah sakit lain dalam hal penyedian air bersih.

Pemantauan kualitas air bersih selalu di lakukan setiap bulan dengan pemeriksaan setiap bulan. Kegiatan kaporitisasi selalu dilakukan setiap pagi.Kegiatan ini memberikan dampak positif dan negatif.Dampak positif yaitu menjaga agar air tidak terdapat bakteri.Akan tetapi dampak negatifnya air di beberapa ruangan terdapat bau kaporit yang sangat kuat.Hal ini membuat ketidaknyamanan pasien.Hal ini dimungkinkan terlalu banyak kaporit yang dibubuhkan disetiap pagi hari.

\section{Pengelolaan Limbah}

Limbah rumah sakit adalah semua limbah yang dihasilkan dari kegiatan rumah sakit dalam bentuk padat, cairan gas yang dapat mengandung mikroorganisme pathogen bersifat infeksius, bahan kimia beracun, dan sebagian bersifat radioaktif.

Limbah rumah sakit bersifat infeksius dan kimia beracun yang dapat mempengaruhi kesehatan manusia, memperburuk kelestarian lingkungan hidup apabila tidak dikelola dengan baik.

Pengelolaan Limbah Rumah Sakit dibagimenjadi 2 jenis yaitu :

\section{a. Limbah Cair}

Limbah cair berasal dari kegiatan di seluruh ruangan.Diantaranya limbah dari unit hemodialisa. Limbah yang dihasilkan antara lain air reject RO. Semua limbah dari seluruh kegiatan ruangan akan dialirkan dan diolah ke IPAL. Di IPAL akan menguraikan bahan-bahan berbahaya yang masih ada di dalam air buangan tersebut. Setelah limbah cair sudah diolah, langsung di buang ke badan sungai yang berada di samping RSUD Banyumas. Jumlah limbah cair yang diolah setiap harinya rata-rata $120 \mathrm{~m}^{3}$.Air outlet dari IPAL setiap bulan sekali di ambil sampel dan diperiksa di laboratorium BPTKL Jogyakarta.

Semua kegiatan di rumah sakit menghasilkan limbah cair.Limbah cair tersebut diolah oleh IPAL.Outlet dari limbah tersebut setiap bulan diambil sampel dan diperiksa oleh BPTKL Jogyakarta.Hasil pemeriksaan menujukan bahwa outletnya bagus dan tidak mencemari badan air.IPAL berkerja selama 24 jam. Untuk mengurangi trouble pada mesin IPAL dapat dilakukan pembersihan sampah sampah kecil bak lift station.

b. Limbah Padat Sampah yang ada di Rumah Sakit Umum Daerah Banyumas bersumber dari seluruh unit ruangan yang ada di Rumah Sakit.Jenis sampah yang dihasilkan adalah sampah medis dan sampah non medis. Sarana pembuangan sampah sementara terbagi menjadi 2, yaitu tempat pembuangan sampah sementara untuk sampah non medis yang tersedia disetiap ruangan dan untuk sampah medis yang tersedia di ruangan-ruangan khusus, disetiap ruangan yang harus mengambilkan tong plastic medis yaitu yang berwarna kuning, sementara untuk sampah non medis yaitu di kantong plastik berwarna hitam.

Sampah infeksius dari tiap-tiap ruangan dibawa menuju TPS limbah B3 yang kemudian dikirim ke PT Tenang Jaya Sejahtera. Setiap pagi petugas cleaning servis mengangkut sampah medis dari per ruangan ke TPS limbah B3. Pengangkutan sampah medis dari pihak PT Tenang Jaya Sejahtera dilakukan setiap 2 hari sekali, yaitu pada hari senin, rabu dan sabtu.Sedangkan sampah non infeksius dibawa ke TPS limbah domestik seminggu tiga kali yang kemudian dikirim ke TPA Gunung Tugel.

Limbah padat terdiri dari padat medis infeksius dan non infeksius. Pengangkutan sampah medis infeksius ke TPS dilakukan setiap pagi hari. Akan tetapi terkadang ada beberapa sampah medis yang masih menumpuk di depan ruangan. Dari segi estetika hal tersebut 
sangat menganggu.Mengingat sampah tersebut sangatlah bau.

Limbah non medis diangkut dan dibuang di gunung tugel.Sampah tersebut masih dapat dimanfaatkan.Salah satunya sampah organik yang berasal dari instalasi gizi yang masih bisa digunakan untuk kompos.

5. Pengendalian Serangga, Tikus dan Binatang Pengganggu Lainnya

Pengendalian serangga, tikus dan binatang pengganggu lainnya di RSUD Banyumas dilakukan oleh pihak ketiga.Pihak ISPL hanya memonitoring kegiatan pest control.

Masih terdapatnya kucing dan tikus di sekitar RSUD Banyumas. Untuk menangani hal tersebut pihak ISPL bekerja sama dengan pihak ketiga dalam menangani vektor dan binatang penganggu. Kegiatan ini sempat berjalan, namun beberapa bulan terakhir ini belum berjalan lagi.Hal ini dikarena tersendat oleh izin dari atasan.Kegiatan tersebut sebenarnya memberikan dampak positif.Dengan adanya kegiatan tersebut dapat mengurangi keberadaan tikus dan kucing.

\section{Penyehatan Udara}

Desinfeksi dan sterilisasi ruangan biasanya dilakukan setelah pasien keluar dengan beberapa cara seperti sterilisasi ruangan dengan menggunakan sinar UV (Ultraviolet) selama 4 jam untuk ukuran ruangan berukuran $3 x 3 \mathrm{~m}^{2}$, gas ozon 30 menit untuk ukuran ruangan berukuran $3 \times 3 \mathrm{~m}^{2}$, dan menggunakan fogger atau ULV (Ultra Low Volume) dengan waktu tunggu 2 jam untuk ukuran ruangan berukuran 3x3 $\mathrm{m}^{2}$. Namun karena banyaknya pasien, sterilisasi ruangan biasanya hanya menggunakan klorin untuk lantai, dinding dan peralatan yang berada di dalam ruang perawatan.

Penyehatan udara yang dilakukan diantaranya yaitu desinfeksi,sterilisasi ruangan dan penanaman pohon yang dapat mengurangi polusi udara. Desinfeksi menggunakan UV dan ozon jarang digunakan.Hal ini karenakan banyaknya pasien yang keluar masuk.Desinfeksi hanya menggunakan klorin pada dinding dan lantai.Walaupun hanya menggunakan klorin, hasil dari usap lantai, usap AC dan kuman udara di ruangan menunjukan hasil yang baik.

\subsection{Gambaran Umum Unit Hemodialisa}

Hemodialisa adalah proses pembersihan darah oleh akumulasi sampah buangan. Hemodialisis digunakan bagi pasien dengan tahap akhir gagal ginjal atau pasien berpenyakit akut yang membutuhkan yang membutuhkan dialisis waktu singkat.Unit Hemodialisa RSUD Banyumas berdiri sejak tahun 2003.Luas dari ruangan hemodialisa ini adalah $518 \mathrm{~m}^{2}$. Terdapat 34 tempat tidur untuk proses pencucian darah.

Proses cuci darah dimulai dari pasien di suntik pada selangkangan hal ini digunakan untuk mengeluarkan darah dari tubuh, lalu di sambungkan dengan selang masuk ke tabung dializer. Ditabung dializer tersebut darah dikontakan dengan air RO. setelah dikontakan dengan air RO darah kembali masuk ke tubuh melalui selang yang berada ditangan. Inti dari proses pencucian adalah pengkontakan darah dengan air RO yang berada ditabung dializer. Mesin pencuci darah digunakan untuk mengatur siklus masuk keluarnya darah ke tubuh serta digunakan untuk mengatur siklus pencucian pada tabung dializer. Proses cuci darah tersebut berlangsung selama 4 jam.

Air yang digunakan untuk pencucian darah ini menggunakan air yang diolah khusus menggunakan sistem Reverse Osmosis ( RO ). Air baku yang digunakan yaitu berasal dari PDAM dan sumur arthesis. Setelah melewati proses RO, alat RO tersebut akan menghasilkan 2 outlet. Yaitu air reject dan air produk. Air produk yang digunakan untuk proses cuci darah. Air produk yang digunakan untuk satu kali proses sebanyak 120 liter. Unit Hemodialisa memiliki 3 mesin RO yaitu, 2 mesin RO merk Fresenius dan 1 mesin RO Sinar Roda.Mesin tersebut bekerja selama 12 jam. Pelayanan pencucian darah dilakukan oleh tenaga kerja berjumlah 25 orang yang terdiri dari dokter jaga, dokter penanggungjawab, perawat,adminitrasi dan cleaning service. Pelayanan Hemodialisis dilakukan dengan pembagian 2 shift. Tenaga kerja dan jumlah tenaga kerja akan disajikan dalam tabel 3.1 dan pembagian shift disajikan dalam tabel 3.2.

Tabel 3.1 Jumlah Tenaga Kerja di Unit Hemodialisa RSUD Banyumas tahun 2017

\begin{tabular}{lll}
\hline No & Status Pekerjaan & Jumlah \\
\hline 1 & Dokter jaga & 1 \\
2. & Dokter penanggung jawab & 1 \\
3 & Perawat & 18 \\
4. & Adminitrasi & 2 \\
5. & Cleaning service & 3 \\
\hline
\end{tabular}


Tabel 3.2 Jadwal Pembagian Shift Kerja di Unit HemodalisaRSUD Banyumas tahun 2017

\begin{tabular}{lll}
\hline No & Waktu Kerja Shift & Keterangan \\
\hline 1. & $07.00-14.00$ & Shift 1 \\
2. & $11.00-18.00$ & Shift 2 \\
\hline
\end{tabular}

\subsection{Pengukuran Debit}

Unit hemodialisa terdapat 3 mesin RO dan 34 mesin pencuci darah. 3 mesin RO tersebut terdiri dari 2 mesin merk Fresenius yang secara gabungan melayani 21 mesin pencuci darah dan 1 mesin RO merk Sinar Roda yang melayani 13 mesin pencuci darah. Pengukuran debit pada air reject menggunakan metode penakaran. Debit air produk didapatkan dengan kutipan lalu dihitung dengan rumus debit, dan debit air baku didapatkan dengan cara menghitung dengan rumus neraca massa. Pengukuran dan perhitungan debit masing-masing mesin RO disajikan pada tabel 3.3

Tabel 3.3 Data Debit Mesin Reverse Osmosis tahun 2017

\begin{tabular}{lllll}
\hline No & \multicolumn{1}{c}{ Nama } \\
& Mesin RO & \multicolumn{3}{c}{ Debit ( liter/detik ) } \\
& Air Reject & $\begin{array}{l}\text { Air } \\
\text { Produk }\end{array}$ & Air Baku \\
\hline 1. & $\begin{array}{l}\text { Mesin } \\
\text { Fresenius } \\
\text { 2. }\end{array}$ & 0,37 & 0,17 & 0,54 \\
& $\begin{array}{l}\text { Mesin } \\
\text { Sinar Roda }\end{array}$ & 0,12 & 0,10 & 0,22 \\
\hline
\end{tabular}

Tabel 3.4 Data Air Baku, Produk dan Reject Mesin RO di Unit Hemodialisa RSUD Banyumas tahun 2017

\begin{tabular}{ccccc}
\hline No & $\begin{array}{c}\text { Nama Mesin } \\
\text { RO }\end{array}$ & $\begin{array}{c}\text { Air } \\
\text { Baku }\end{array}$ & $\begin{array}{c}\text { Air } \\
\text { Produk }\end{array}$ & $\begin{array}{c}\text { Air } \\
\text { Reject }\end{array}$ \\
\hline 1. & Mesin & $23,3 \mathrm{~m}^{3}$ & $7,5 \mathrm{~m}^{3}$ & $15,9 \mathrm{~m}^{3}$ \\
2. & $\begin{array}{c}\text { Fresenius } \\
\text { Mesin Sinar } \\
\text { Roda }\end{array}$ & $9,7 \mathrm{~m}^{3}$ & $4,6 \mathrm{~m}^{3}$ & $5,1 \mathrm{~m}^{3}$ \\
& & & \\
\hline
\end{tabular}

Tabel 3.5 Prosentase Rejeksi Mesin RO di Unit Hemodialisa RSUD Banyumas tahun 2017

\begin{tabular}{ccc}
\hline No & Nama Mesin RO & $\begin{array}{c}\text { Prosentase Air } \\
\text { Reject }\end{array}$ \\
\hline 1. & Mesin Fresenius & $68 \%$
\end{tabular}

2. Mesin Sinar Roda

$54 \%$

Kualitas air reject dan prosentase rejeksi membran dari ion $\mathrm{Ca}^{++}$dan $\mathrm{Mg}^{++}$dapat digunakan untuk melihat kualitas kinerja membran pada masing-masing mesin. Prosentasi rejeksi membran disajikan pada tabel 3.6

Tabel 3.6 Prosentase Rejeksi Kesadahan Membran Mesin RO di Unit Hemodialisa RSUD Banyumas tahun 2017

\begin{tabular}{|c|c|c|c|}
\hline No & $\begin{array}{l}\text { Nama } \\
\text { Mesin }\end{array}$ & $\begin{array}{l}\text { Prosentasi } \\
\text { Rejeksi } \\
\text { Kesadahan } \\
\text { Membran Mesin } \\
\text { Reverse Osmosis }\end{array}$ & $\begin{array}{l}\text { Referensi } \\
*)\end{array}$ \\
\hline 1. & $\begin{array}{l}\text { Fresenius } \\
1\end{array}$ & $87,1 \%$ & $95-99 \%$ \\
\hline 2. & $\begin{array}{l}\text { Fresenius } \\
2\end{array}$ & $11,1 \%$ & 95-99 \% \\
\hline 3. & $\begin{array}{l}\text { Sinar } \\
\text { Roda }\end{array}$ & $22,2 \%$ & $95-99 \%$ \\
\hline
\end{tabular}

*) Referensi menggunakan manual book operating instruction mesin Fresenius

Pengukuran debit air baku yang digunakan dalam sehari untuk cuci darah sebanyak $33,1 \mathrm{~m}^{3}$. Air reject yang dibuang sebanyak $21 \mathrm{~m}^{3}$. Lebih jelasnya dapat dilihat pada tabel 4.4. Menurut A.J Hartomo, M.C Widiatmoko, 1994 rejeksi membran bisa mencapai $95 \%$.

Rejeksi mesin gabungan Fresenius yaitu 67,9 \% dan rejeksi mesin Sinar Roda 52,5 \%. Melihat presentase reject yang dihasilkan, rejeksi mesin Fresenius dan Sinar Roda tersebut masih dalam keadaan ideal atau normal yaitu dibawah $95 \%$. Rejeksi tersebut bisa dikarenakan air baku yang digunakan memang sudah baik, sehingga membran tidak terlalu bekerja keras dalam mengolah.

Menurut manual book operating instruction mesin Fresenius rejeksi membran divalen ion $\mathrm{Ca}^{++}$ $\mathrm{Mg}^{++}$yaitu 95 - 99\%. Perhitungan rejeksi $\mathrm{Ca}^{++} \mathrm{Mg}^{++}($ kesadahan ) dapat dlihat pada tabel 4.10 hasil perhitungan tersebut menunjukan semua rejeksi membran tidak mencapai range 95-99\%. Perhitungan dan kualitas airreject dapat mengetahui kinerja membran masing-masing mesin.

Melihat banyaknya air reject yang dibuang dapat dilihat pada tabel. 4.4 yang seharusnya dapat dimanfaatkan dengan atau tanpa perlakuan sesuai dengan kualitas air reject masing-masing mesin.

\subsection{Hasil Pemeriksaan Kualitas Air Reject dan Air Baku}


Pengambilan dan pemeriksaan sampel dilakukan pada air baku (air inlet) dan air reject pada masing-masing mesin RO. Kualitas air baku dan air reject diperiksa dengan parameter fisik, kimia dan bakteriologis. Hasil pemeriksaan kualitas air baku dan air reject disajikan pada tabel 4.6 sampai 4.9.

Tabel 3.7 Kualitas Air Baku Mesin RO di Unit Hemodialisa RSUDBanyumas tahun 2017

\begin{tabular}{|c|c|c|c|}
\hline No & Parameter & $\begin{array}{l}\text { Kadar } \\
\text { maksimum yang } \\
\text { diperbolehkan } \\
* \text { ) }\end{array}$ & $\begin{array}{l}\text { Hasil } \\
\text { pemeriksa } \\
\text { an }\end{array}$ \\
\hline \multirow[t]{3}{*}{ A. } & $\begin{array}{l}\text { Fisik } \\
\text { 1. Suhu }\end{array}$ & $\begin{array}{l}\text { Suhu udara } \pm 3^{\circ} \\
\text { C }\end{array}$ & $\begin{array}{l}\text { Suhu air : } \\
27,7^{\circ} \mathrm{C} \\
\text { Suhu udara } \\
: 30,5^{\circ} \mathrm{C}\end{array}$ \\
\hline & 2. Bau & Tidak berbau & $\begin{array}{l}\text { Tidak } \\
\text { berbau }\end{array}$ \\
\hline & $\begin{array}{ll}\text { 3. } & \text { Rasa } \\
\text { 4. } & \text { Warna } \\
\text { 5. } & \text { Kekeruhan } \\
\text { 6. } & \text { TDS }\end{array}$ & $\begin{array}{l}\text { Tidak berasa } \\
15 \mathrm{TCU} \\
5 \mathrm{NTU} \\
500 \mathrm{mg} / 1\end{array}$ & $\begin{array}{l}\text { Tidak } \\
\text { berasa } \\
1,4 \text { TCU } \\
0,89 \mathrm{NTU} \\
159 \mathrm{mg} / 1\end{array}$ \\
\hline \multirow[t]{2}{*}{ B. } & $\begin{array}{l}\text { Kimia } \\
\begin{array}{lll}\text { 7. } & \text { Kesadahan } \\
& \text { a. } & \mathrm{Ca}^{++} \\
\text {b. } & \mathrm{Mg}^{++} \\
\text {c. } & \text { Total }\end{array}\end{array}$ & 500 & $\begin{array}{l}8,75 \\
21,60 \\
30,35\end{array}$ \\
\hline & $\begin{array}{ll}\text { 8. } & \text { Sisa Chlor } \\
\text { 9. } & \text { Ph } \\
\text { 10. } & \text { Daya } \\
\text { Hantar } \\
\text { Listrik }\end{array}$ & $\begin{array}{l}5 \mathrm{mg} / \mathrm{l} \\
6,5-8,5\end{array}$ & $\begin{array}{l}0,2 \mathrm{mg} / \mathrm{l} \\
8,2 \\
265 \\
\text { umhos/cm }\end{array}$ \\
\hline \multirow[t]{2}{*}{ C. } & $\begin{array}{l}\text { Bakteriologis } \\
\text { 11. e.coli }\end{array}$ & $\begin{array}{l}0 \text { Jumlah per } \\
100 \mathrm{ml} \text { sampel }\end{array}$ & 0 \\
\hline & $\begin{array}{l}\text { 12. Total } \\
\text { coliform }\end{array}$ & $\begin{array}{l}0 \text { Jumlah per } \\
100 \mathrm{ml} \text { sampel }\end{array}$ & 0 \\
\hline
\end{tabular}

*)Baku mutu menggunakan Permenkes No 492/MENKES/PER.IV/2010
Tabel 3.8 Kualitas Air Reject Mesin RO Fresenius 1 di Unit Hemodialisa RSUD Banyumas tahun 2017

\begin{tabular}{|c|c|c|c|}
\hline No & Parameter & $\begin{array}{l}\text { Kadar } \\
\text { maksimu } \\
\text { m yang } \\
\text { diperbole } \\
\text { hkan *) } \\
\end{array}$ & $\begin{array}{l}\text { Hasil } \\
\text { pemeriksaan }\end{array}$ \\
\hline \multirow[t]{7}{*}{ A. } & Fisik & & \\
\hline & 1. Suhu & $\begin{array}{l}\text { Suhu } \\
\text { udara } \pm \\
3^{\circ} \mathrm{C}\end{array}$ & $\begin{array}{l}\text { Suhu Air : } \\
27,7^{\circ} \mathrm{C} \\
\text { Suhu Udara : } \\
29^{\circ} \mathrm{C}\end{array}$ \\
\hline & 2. Bau & $\begin{array}{l}\text { Tidak } \\
\text { berbau }\end{array}$ & Tidak berbau \\
\hline & 3. Rasa & $\begin{array}{l}\text { Tidak } \\
\text { berasa }\end{array}$ & Tidak berasa \\
\hline & 4. Warna & $15 \mathrm{TCU}$ & 1,3 TCU \\
\hline & 5. Kekeruhan & $5 \mathrm{NTU}$ & 0,16 NTU \\
\hline & 6. TDS & 500 mg/l & 289 mg/l \\
\hline \multirow[t]{10}{*}{ B. } & Kimia & & \\
\hline & 7. Kesadahan & & \\
\hline & a. $\mathrm{Ca}^{++}$ & & 16,00 \\
\hline & b. $\mathrm{Mg}^{++}$ & & 40,80 \\
\hline & c. Total & 500 & 56,80 \\
\hline & 8. Sisa Chlor & $5 \mathrm{mg} / \mathrm{l}$ & $0,1 \mathrm{mg} / \mathrm{l}$ \\
\hline & 9. $\mathrm{Ph}$ & $6,5-8,5$ & 8 \\
\hline & 10. Daya & & 482 umhos/cm \\
\hline & Hantar & & \\
\hline & Listrik & & \\
\hline \multirow[t]{3}{*}{ C. } & Bakteriologis & 0 Jumlah & 240 \\
\hline & 11. e.coli & $\begin{array}{l}\text { per } 100 \\
\text { ml }\end{array}$ & \\
\hline & $\begin{array}{l}\text { 12. Total } \\
\text { coliform }\end{array}$ & $\begin{array}{l}0 \text { Jumlah } \\
\text { per } 100 \\
\text { ml } \\
\text { sampel }\end{array}$ & 240 \\
\hline
\end{tabular}

*)Baku mutu menggunakan Permenkes No 492/MENKES/PER.IV/2010 
Tabel 3.9 Kualitas Air Reject Mesin RO Fresenius2 di Unit Hemodialisa RSUD Banyumas tahun 2017

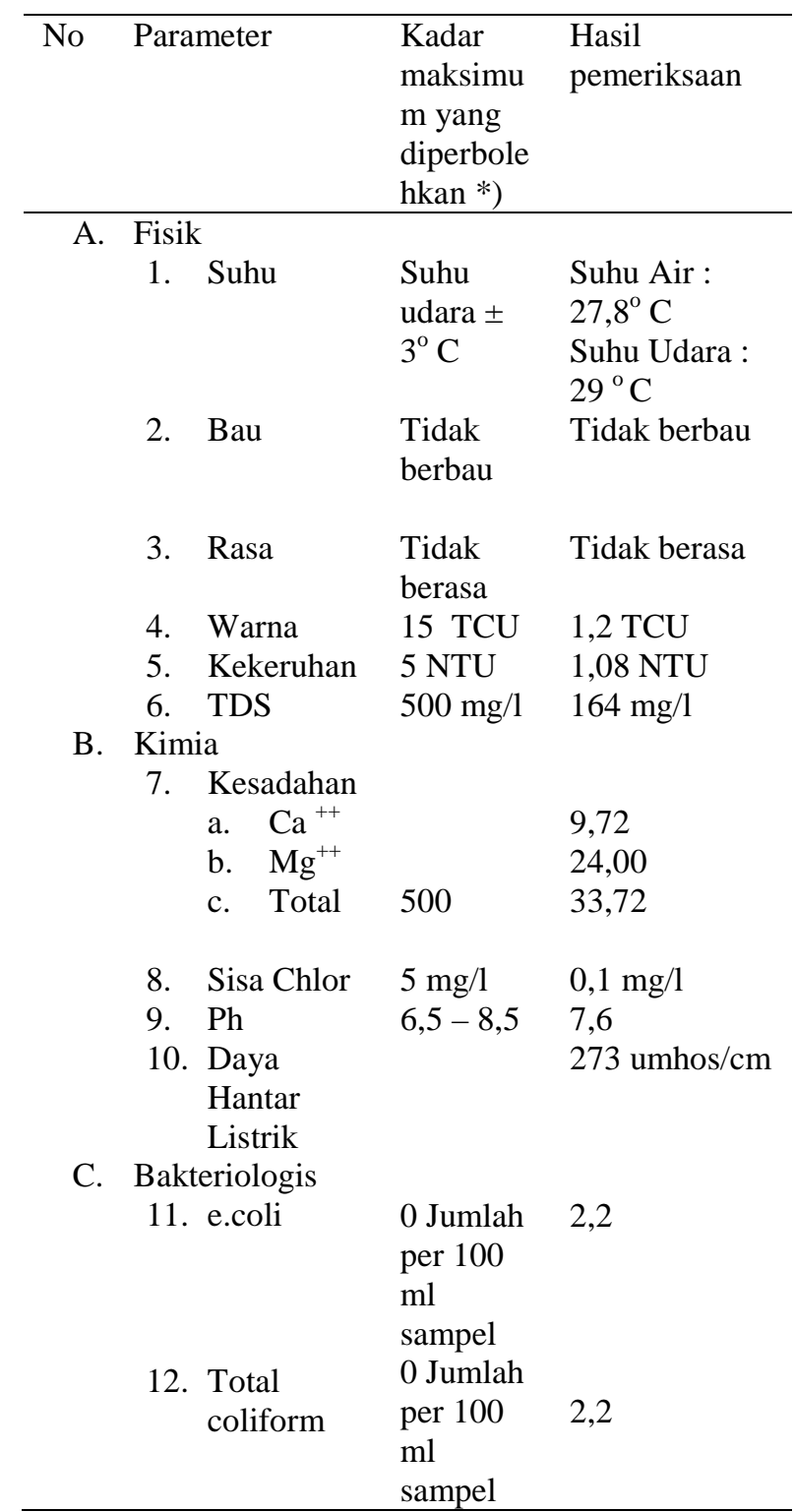

*)Baku mutu menggunakan Permenkes No 492/MENKES/PER.IV/2010
Tabel 3.10 Kualitas Air Reject Mesin RO Sinar Roda di Unit Hemodialisa RSUD Banyumas tahun 2017

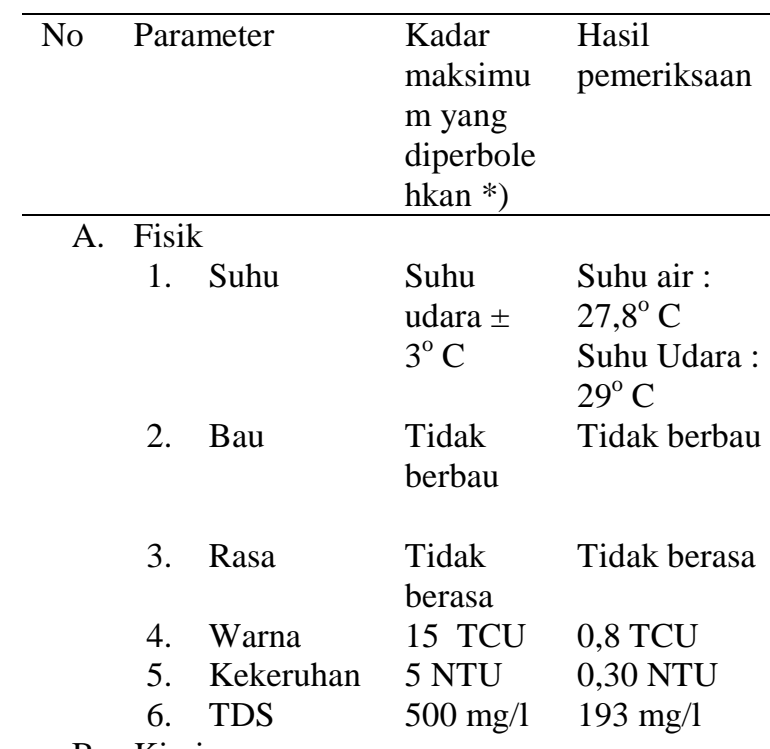

B. Kimia

7. Kesadahan
a. $\mathrm{Ca}^{++}$
b. $\mathrm{Mg}^{++}$
10,70
c. Total
500
26,40
47,10

8. Sisa Chlor

$5 \mathrm{mg} / \mathrm{l}$

$0,1 \mathrm{mg} / \mathrm{l}$

9. $\mathrm{Ph}$

$6,5-8,5$

8

10. Daya

Hantar

Listrik

C. Bakteriologis

11. e.coli

0 Jumlah $\quad 240$

per 100

$\mathrm{ml}$

12. Total sampel 240

coliform 0 Jumlah

per 100

$\mathrm{ml}$

sampel

*)Baku mutu menggunakan Permenkes No 492/MENKES/PER.IV/2010

Kualitas dari air baku dan air reject masing masing mesin dilakukan pemeriksaan dengan parameter fisik kimia dan bakteriologis. Permenkes 492 tahun 2010 tentang persyaratan air minum mempersyaratkan bahwa E.coli dan Coliform harus 0 . Kualitas air baku dan masing-masing air reject dapat dilhat pada tabel 4.6 sampai 4.9.

Kualitas air baku sudah memenuhi syarat sebagai bahan baku untuk pengolahan RO. Kualitas air reject mesin Fresenius 2 setelah dibandingkan 
dengan Permenkes 416 tahun 1990 tentang syaratsyarat dan pengawasan kualitas air, dapat dimanfaatkan sebagai air bersih yang dapat digunakan sebagai kebutuhan air kamar mandi atau wastafel.

Kualitas fisik dan kimia air reject mesin Fresenius 1 dan Sinar Roda sudah memenuhi syarat sebagai air minum. Akan tetapi pada kualitas bakteriologis pada air reject mesin Fresenius 1 dan Sinar Roda menunjukan bahwa tidak memenuhi syarat untuk air minum sesuai permenkes 492 tahun 2010.Hal tersebut dikarenakan terdapat E.coli dan Colifrom yang sangat tinggi yaitu 240 per $100 \mathrm{ml}$ sampel. Akan tetapi, didalam air tersebut mengandung sisa chlor sebanyak 0,1 mg/l.

Menurut Azhar Fauadi (2012) dalam penelitian disebutkan bahwa distribusi total Coliform dalam air bersih disebabkan banyak faktor, yaitu faktor fisik dan kimiawi. Hal tersebut dikarenakan kemampuan mikroorganisme untuk bertahan hidup sangatlah tinggi.Meskipun pada keadaan air yang mengandung klorin dengan konsentrasi tertentu yang menurut teori sudah cukup untuk desinfeksi dan dapat membunuh semua mikroba dalam air tersebut. Akan tetapi terdapat beberapa faktor lain diantaranya yang dapat mendukung untuk kelangsungan hidupnya atau terdapatnya mikroba dalam air, yaitu diantaranya faktor kekeruhan, kebocoran dan lain sebagainya. Keadaan mikroorganisme dalam jaringan distribusi masih belum terlalu dipahami, masih banyak hal yang harus diteliti untuk memahami keberadaan mikroorganisme dalam pipa jaringan distribusi.

Kondisi yang dapat mempengaruhi pertumbuhan Coliform diantaranya yaitu adanya substrat, suhu air, korosi, keberadaan sedimen dan residual desinfektan (LeChevallier 1990; LeChevallier at al. 1996 dalam Azhar 2012)

Klorin dapat bekerja sebagai desinfektan jika berada dalam air dengan $\mathrm{pH}$ 7.Semakin tinggi $\mathrm{pH}$ air dapat mengakibatkan proses klorinasi tidak efektif karena 90\% dari asam hipoklorit ( $\mathrm{HOCl}$ ) itu akan mengalami ionisasi menjadi ion hipoklorit sehingga khasiat desinfektan yang dimiliki klor akan menjadi lemah atau berkurang (Elly dalam Dian, 2007). Sisa chlor merupakan kadar chlor setelah digunakan untuk mengoksidasi zat organik dan logam.

Hasil pemeriksaan kualitas bakteriologis dan sisa chlor pada mesin Fresenius 1 dan Sinar Roda menunjukan hasil yang kontradiksi.Menurut teori apabila masih terdapat sisa chlor, harusnya tidak terdapat bakteri. Kontradiksi merupakan kesalahan yang dapat di iventarisir antara lain terdapat kesalahan dalam pengambilan sampel ataupun pemeriksaan sampel.
Pengambilan sampel dan pemeriksaan sisa chlor, ph dan suhu dilakukan oleh peneliti.Setelah dilakukan konfirmasi dengan Laboratorium, petugas tidak melakukan kesalahan dalam memeriksa sampel. Setelah dilakukan penelusuran tentang sistem jaringan distribusi penyediaan air bersih, didapatkan bahwa tempat pengambilan sampel air baku yang tidak tepat.

Alur distribusi air baku untuk RO yaitu dari ground tank dipompa naik ke lantai 3 ditampung pada toren dan didistribusikan lagi secara gravitasi ke ruang RO dan ruang RO ditampung lagi pada toren RO. Seharusnya untuk hasil yang lebih tepat dapat dilakukan pengambilan sampel air baku di toren atau tempat penampungan air baku yang berada didekat alat RO.

Kontradiksi dapat terjadi pada kelemahan alat komparator disk untuk pemeriksaan sisa chlor. Alat tersebut mempunyai kelemahan yaitu batas range hanya dari 0,1 - 0,5 mg/l. Saat pembacaan hasil sisa chlor warna pada cuvet dan warna disk nya tidak sama. Yakni hanya mirip. Berhubung range paling bawah $0,1 \mathrm{mg} / \mathrm{l}$ maka peneliti menganggap $0,1 \mathrm{mg} / \mathrm{l}$ yang hampir mirip warna pada disk.

Meskipun demikian terdapat kasus penelitian Duta Andika, dkk (2013) dalam penelitiannya disebutkan bahwa ada hubungan antara kadar sisa chlor dengan E. coli sesudah pengolahan air. Pada penelitian tersebut menyebutkan bahwa terdapat $E$. coli 7, 28 per $100 \mathrm{ml}$ sampel pada sisa chlor 0,13 $\mathrm{mg} / \mathrm{l}$.

Parameter kimia fisik pada mesin Fresenius dan Sinar Roda sudah memenuhi syarat sebagai air minum sesuai Permenkes 492 tahun 2010 tentang persyaratan air minum. Akan tetapi hasil pemeriksaan parameter bakteriologis air reject pada semua mesin RO menunjukan tidak memenuhi syarat untuk dimanfaatkan sebagai air minum. Hal ini dikarenakan adanya $E$ coli dan Coliform dalam air tersebut.Namun demikian dari aspek sisa chlor dapat dimanfaatkan untuk air minum. Dari data tersebut air rejectdapat dimanfaatkan untuk air minum jika dilakukan treatment dengan melakukan desinfeksi. Menurut Djasio Sanropie, 1993 desinfeksi dapat dilakukan secara fisik yaitu direbus, secara radiasi yaitu menggunakan sinar ultra violet dan secara menambahkan chlorine.

Sebagaimana pada tabel 4.6 dan 4.8 jika dibandingkan dengan PP nomor 82 tahun 2001 kualitas air reject mesin Fresenius dan Sinar Roda termasuk klasifikasi kelas dua, tiga dan empat. Sehingga dapat dimanfaatkan secara langsung untuk pembudidayaan ikan air tawar, peternakan,mengairi pertanaman.

Air reject dapat dimanfaatkan tetapi harus mengalami pengolahan terlebih dahulu, diantaranya 
air reject dapat dimanfaatkan sebagai bahan baku aquades, sebagai air untuk pembuatan obat (farmasi), dan sebagai bahan proses sterilisasi alat kesehatan CSSD .

Dapat dimanfaatkan untuk bidang farmasi dengan melakukan destilasi. Dapat dimanfaatkan untuk bahan baku proses RO sebagai air strerilisasi alat kesehatan pada CSSD dengan cara air reject di desinfeksi.

\section{Kesimpulan}

1. Debit air reject 0,49 liter/detik, air produk 0,27 liter/detik, air baku 0,78 liter/detik.

2. Kualitas fisik air baku yaitu suhu air $27,7{ }^{\circ} \mathrm{C}$, suhu udara $30,5^{\circ} \mathrm{C}$, tidak berbau, tidak berasa, warna 1,4 TCU, kekeruhan 0,89 NTU, TDS $159 \mathrm{mg} / \mathrm{l}$. Kualitas fisik air reject yaitu suhu air $27,7{ }^{\circ} \mathrm{C}$ suhu udara $29^{\circ} \mathrm{C}$, tidak berbau, tidak berasa, warna 1,3 TCU,kekeruhan 0,16 NTU,TDS 289 mg/l. Menurut Permenkes 492 tahun 2010 tentang Persyaratan Kualitas Air Minum, hasil pengukuran parameter fisik dari air baku dan air reject memenuhi syarat.

3. Kualitas kimia air baku yaitu kesadahan $\mathrm{Ca}^{++}$ 8,75, $\mathrm{Mg}^{++}$21,60, sisa chlor 0,2 mg/l, $\mathrm{pH} \mathrm{8,2} \mathrm{,}$ daya hantar listrik 265 umhos/cm. Kualitas kimia ai reject yaitu kesadahan $\mathrm{Ca}^{++} 16, \mathrm{Mg}^{++}$ 40,8 , sisa chlor $0,1 \mathrm{mg} / \mathrm{l}, \mathrm{pH} 8$, daya hantar listrik 482 umhos/cm. Menurut Permenkes 492 tahun 2010 tentang Persyaratan Kualitas Air Minum, hasil pemeriksaan parameter kimia dari air baku dan air reject memenuhi syarat.

4. Kualitas bakteriologis air baku yaitu E coli dan Coliform 0 per $100 \mathrm{ml}$ sampel. Kualitas bakteriologis air reject yaitu E.coli dan Coliform 240 per $100 \mathrm{ml}$ sampel. Menurut Permenkes 492 tahun 2010 tentang Persyaratan Kualitas Air Minum, hasil pemeriksaan parameter bakteriologis air baku yaitu memenuhi syarat dan untuk air reject tidak memenuhi syarat.

5. Menurut Permenkes 32 tahun 2017 tentang Standar Baku Mutu Kesehatan Lingkungan Dan Persyaratan Kesehatan Air Untuk Keperluan Higiene Sanitasi, Kolam Renang, Solus Per Aqua, Dan Pemandian Umum air reject tidak memenuhi syarat secara bakteriologis untuk keperluan higiene sanitasi.

6. Menurut Permenkes 492 tahun 2010 tentang persyaratan air minum, air baku sudah memenuhi syarat sebagai air baku untuk Reverse Osmosis, semua air reject mesin RO tidak memenuhi syarat sebagai air minum.

7. Menurut Permenkes 416 tahun 1990 tentang syarat-syarat dan pengawasan kualitas, air reject mesin Fresenius 2 memenuhi syarat sebagai air bersih.

8. Menurut PP no 82 tahun 2001 tentang pengelolaan kualitas air dan pengendalian pencemaran air, air reject mesin Fresenius 1 dan Sinar Roda memenuhi syarat kelas 2,3,4.

9. Air rejectdapat dimanfaatkan dengan atau tanpa perlakuan. Air reject dapat dimanfaatkan untuk bidang farmasi dengan teknik destilasi, dapat dimanfaatkan sebagai bahan baku proses strerilisasi alat kesehatan di CSSD RSUD Banyumas.

Ucapan Terima Kasih : Pihak RSUD dan Unit Hemodialisa Banyumas yang telah mengizinkan dan membantu penelitian.

\section{Daftar Pustaka}

Ace Yati Hyati,Biskar,Cucu Cakrawati,Dailami Luthfi,Hartojo, Hening Darpito,Muedjadi Hardyanto,Muhadjir,Nurul Aini,Sri Hayana,Trisiana Giyantini,2007,Pelatihan Penyehatan Air,Jakarta:Departemen Kesehatan Direktorat Jendral PP dan PL Direktorat Penyehatan Lingkungan

A.J.Hartomo,M.C.Widiatmoko,1994,Teknologi Membran Permunian Air, Yogyakarta:Andi Offset.

Arie Herlambangan,Haryoto Indriatmoko,Heru Dwi Wahjono,Ikbal,Nugro Rahadjo,Nusa Idaman Said,R.Haryoto Indriatmoko,Rudi Nugroho,Ruliasih Marsidi,Satmoko Yudo,Setiyono,Wahyu Widayat,19992010,Materi Pelatihan Teknologi Pengolahan Air Bersih,Jakarta:Badan Pengkaji dan Penerapan Teknologi

Azhar Fuadi,2012, Pengaruh Residual Khlorin Terhadap Kualitas Mikrobiologi Pada Jaringan Distribusi Air Bersih (Studi Kasus : Jaringan Distribusi Air Bersih IPA Cilandak), Jakarta; Universitas Indonesia

Bambang Priyambodo,2014,Media untuk Belajar \& Berbagi Mengenai Manajemen Farmasi Indonesia, https://priyambodo1971.wordpress.com/cpob/s arana-penunjang-kritis-industri-farmasi/sistem-pengolahan-air-spa/

Basuki Hardjojo,2005,Pengukuran dan Analisis Kualitas Air,Jakarta:Universitas Terbuka

Djasio Sanropie,Sumini,Tri Prasetyo,Waluyo Jati,Wibowo Soesanto,1983,Penyediaan Air Bersih,Departerment Kesehatan RI 
Dian Wahyu Cita, Retno Adriyani,Kualitas Air Dan Keluhan Kesehatan Pengguna Kolam Renang Di Sidoarjo, Surabaya; Universitas Airlangga

Duta Andhika, dkk,2013, Kadar Sisa Chlor Dan Kandungan Bakteri E.Coli Perusahaan Air Minum Tirta Moedal Semarang Sebelum Dan Sesudah Pengolahan, Semarang;Universitas Diponegoro

Fresenius Medical Care Technologies (Malaysia),Buku panduan Reverse Osmosis Unit Enviro MX Series Operating Instruction

Hefni Effendi,2003,Telaah Kualitas

Air,Yogyakarta:Kanisius

Hermantoro1, Rengga Arnalis Renjani,2014,Studi Pemanfaatan Water Rejected Reverse Osmosis untuk Kebutuhan Air Domestik dan Sebagai Boiler Feed Water di Pabrik Kelapa Sawit, Yogyakarta

G.Alaerts,Sri Sumerti Santika,Supratiknyo,1987,Metoda Penelitian Air,Surabaya:Usaha Nasional

Mangku Sitepoe,1997,Air untuk Kehidupan Pencemaran Air dan Usaha Pencegahannya,Jakarta:PT.Grasindo

Menteri Kesehatan, RI, 1990, Peraturan Meteri Kesehatan RI Nomor 416/MENKES/PER/IX/1990 Tentang Syaratsyarat dan Pengawasan Kualitas Air, Jakarta

Menteri Kesehatan, RI, 2004, Keputusan Menteri Kesehatan RI Nomor 1204/SK/X/2004 Tentang Persyaratan Kesehatan Lingkungan Rumah Sakit, Jakarta

Menteri Kesehatan, RI, 2010, Peraturan Meteri Kesehatan RI Nomor 492/MENKES/PER/IV/2010 Tentang Persyaratan Kualitas Air Minum, Jakarta

Nusa Idaman Said,Wahyu Widayat,2010,Teknologi Biofiltrasi dan Ultrafiltrasi untuk Pengolahan Air Minum,Jakarta:Badan Pengkaji dan Penerapan Teknologi

KRT Tjokrokusumo,1995,Pengantar Konsep Teknologi Bersih Khusus Pengelolaan dan Pengolahan Air,Yogyakarta:Sekolah Tinggi Teknik Lingkungan YLH

PP, 2001, Peraturan Pemerintah Nomor 82 Tahun 2001 Tentang Pengelolaan Kualitas Airdan Pengendalian Pencemaran Air, Jakarta

Qwaterindonesia.2011.at www.qwaterindonesia.com/airberkualitas/teknologi-reverse-osmosis-ro

Sugeng Abdullah,Suparmin,Arif Widyanto,2010,Bahan Ajar Laboratorium Kesehatan Lingkungan,Politeknik Kesehatan Depkes Semarang

Sugeng Abdullah, 2010, Pengukuran Kapasitas Debit, at http://sugengzend.blogspot.co.id/2010/11/pen gukuran-kapasitas-air.html Diakses Januari 2017.

Waton-Nuliss.2013. Pengertian, Indikasi, Proses Tentang Hemodialisa. At watonnuliss.blogspot.com/2013/03/hemodialisa.htm 